\title{
Sex estimation of Brazilian skulls using discriminant analysis of cranial
}

\section{measurements}

\section{Estimativa sexual de crânios brasileiros utilizando análise discriminante de mensurações cranianas \\ Estimación del sexo de cráneos brasileños mediante análisis discriminante de medidas craneales}

\author{
Thais Torralbo Lopez-Capp \\ ORCID: https://orcid.org/0000-0002-4571-4459 \\ Faculdade de Odontologia da Universidade de São Paulo, Brazil \\ E-mail:thais.lopez@usp.br \\ Luiz Airton Saavedra de Paiva \\ ORCID: https://orcid.org/0000-0002-3666-6977 \\ Instituto de Ensino e Pesquisa em Ciências Forenses, Brazil \\ E-mail: luizairtonsaavedra@ig.com.br \\ Marcio Yara Buscatti \\ ORCID: https://orcid.org/0000-0001-5230-3773 \\ Universidade Paulista, Brazil \\ E-mail: buscatti@usp.br \\ Edgard Michel-Crosato \\ ORCID: https://orcid.org/0000-0001-8559-9769 \\ Faculdade de Odontologia da Universidade de São Paulo, Brazil \\ E-mail:michelcrosato@usp.br \\ Maria Gabriela Haye Biazevic \\ ORCID: https://orcid.org/0000-0001-6326-5805 \\ Faculdade de Odontologia da Universidade de São Paulo, Brazil \\ E-mail: biazevic@usp.br
}

\begin{abstract}
The present study aimed to evaluate the accuracy of cranial measurements for estimation of sex in the Brazilian population and develop discriminant formulas with a reference table to be used as a reference on Brazilian Forensic Anthropology studies. The total sample was comprised of 100 skulls from an osteological collection and 200 computed tomography. The measure's protocol comprised 51 cranial measurements and it was based on 29 cranial landmarks. The results of the univariate comparison of cranial measurements showed a higher mean for male skulls, except for the following variables: zygoorbital breadth (diff=-2.21), interorbital breadth (diff=-0.72), nasal breadth (diff $=-0.19)$ and palatal breadth (diff=-0.01). The paired test $t$ analysis showed that the variables with the highest sexual dimorphism were maximum cranial length $(\mathrm{p}<0.001)$, Basion-Bregma height $(\mathrm{p}<0.001)$, cranial base length $(p<0.001)$, nasal height $(p<0.001)$, bizigomatic breadth $(p<0.001)$, left Porion-Mastoidale length $(p<0.001)$, right Asterion-Mastoidale length $(\mathrm{p}<0.001)$, right $(\mathrm{p}<0.001)$ and left $(\mathrm{p}<0.001)$ mastoid length. The multivariate discriminant analysis of the cranial measurements of the Brazilian sample showed a percentage of accuracy between $82-90 \%$. The analysis of the metric variables showed that there is sexual dimorphism between skulls in the sample. The regression formulas and the reference table presented satisfactory results for sex estimation in a Brazilian population. The validation process of the discriminant functions and the reference table showed a percentage of accuracy between-74.2-85.7\% The analysis of the metric variables showed that there is sexual dimorphism between skulls of the analyzed sample.
\end{abstract}

Keywords: Skull; Sex determination analysis; Forensic anthropology; Forensic odontology.

\section{Resumo}

O presente estudo teve como objetivo avaliar a acurácia das medidas cranianas para estimativa do sexo na população brasileira e desenvolver fórmulas discriminantes com uma tabela de referência a ser usada como referência nos estudos da Antropologia Forense brasileira. A amostra total foi composta por 100 crânios de amostra osteológica e 200 tomografias computadorizadas de indivíduos vivos. O protocolo da medida compreendeu 51 medições cranianas e foi baseado em 29 marcos cranianos. Os resultados da comparação univariada das medidas cranianas mostraram uma média maior para crânios masculinos, exceto para as seguintes variáveis: largura zigoorbital (diff $=-2,21$ ), largura interorbital (diff $=-0,72)$, largura nasal $($ diff $=-0,19)$ e largura palatal (diff $=-0,01)$. A análise do teste $t$ pareado mostrou que as variáveis com maior dimorfismo sexual foram comprimento máximo do crânio ( $\mathrm{p}<0,001)$, altura do Basion-Bregma ( $\mathrm{p}<0,001)$, comprimento da base do crânio ( $\mathrm{p}<0,001)$, altura nasal ( $\mathrm{p}<0,001)$, largura bizigomática ( $\mathrm{p}<0,001$ ), comprimento de Porion-Mastoidale esquerdo ( $\mathrm{p}<0,001$ ), comprimento de Asterion-Mastoidale direito ( $\mathrm{p}$ 
$<0,001)$, comprimento de mastoide direita $(\mathrm{p}<0,001)$ e esquerda ( $\mathrm{p}<0,001)$. A análise discriminante multivariada das medidas cranianas da amostra brasileira mostrou um percentual de acerto entre $82-90 \%$. As fórmulas de regressão e a tabela de referência apresentaram resultados satisfatórios para estimativa de sexo em uma população brasileira. $\mathrm{O}$ processo de validação das funções discriminantes e da tabela de referência apresentou um percentual de acerto entre 74,2-85,7\%. A análise das variáveis métricas mostrou que há dimorfismo sexual entre os crânios da amostra analisada.

Palavras-chave: Crânio; Análise para determinação do sexo; Antropologia forense; Odontologia forense.

\section{Resumen}

El presente estudio tuvo como objetivo evaluar la precisión de las medidas craneales para estimar el sexo en la población brasileña y desarrollar fórmulas discriminantes con una tabla de referencia para ser utilizada como referencia en los estudios de Antropología Forense Brasileña. La muestra total consistió en 100 cráneos de uma colection osteológica y 200 imagenes de tomografia computadorizada. El protocolo de medición comprendió 51 mediciones craneales y se basó en 29 puntos de referencia craneales. Las mediciones se realizaron directamente en los cráneos, utilizando un calibre digital, una brújula curva y un transportador. Los resultados de la comparación univariante de medidas craneales mostraron una media más alta para los cráneos masculinos, excepto por las siguientes variables: ancho zygoorbital (diff $=-2.21$ ), ancho interorbital (diff $=-0.72$ ), ancho nasal $($ diff $=-0.19)$ y ancho palatino (diff $=-0.01$ ). El análisis de la prueba t pareada mostró que las variables con mayor dimorfismo sexual fueron la longitud máxima del cráneo ( $\mathrm{p}<0,001)$, la altura de Basion-Bregma ( $<<0,001)$, la longitud de la base del cráneo ( $\mathrm{p}<0,001)$, la altura nasal ( $\mathrm{<}<0,001)$. ), ancho bicigomático ( $<<0,001)$, longitud del Porion-Mastoideo izquierdo ( $\mathrm{p}<0,001)$, largo del Asterion-Mastoidale derecho ( $<<0,001)$, largo del mastoideo derecho $(\mathrm{p}<0,001)$ e izquierdo (p) <0,001). El análisis discriminante multivariado de las medidas craneales de la muestra brasileña mostró un porcentaje de aciertos entre $82-90 \%$. El análisis de variables métricas mostró que existe dimorfismo sexual entre los cráneos de la muestra. Las fórmulas de regresión y la tabla de referencia mostraron resultados satisfactorios para estimar el sexo en una población brasileña. El proceso de validación de las funciones discriminantes y la tabla de referencia presentaron un porcentaje de aciertos entre -74,2-85,7\%. El análisis de variables métricas mostró que existe dimorfismo sexual entre los cráneos de la muestra analizada.

Palabras clave: Cráneo; Análisis para determinación de sexo; Antropología forense; Odontología forense.

\section{Introduction}

Forensic Anthropology is the science based on the application of physical and biological anthropological theories and methodologies, particularly those related to the analysis and identification of human remains skeletized, charred or in advanced stages of decomposition to solve legal questions. Forensic Anthropology has as main object of study to contribute with the identity and identification of the human being, which since the 14th century has been widely studied and improved (Cattaneo, 2007; Dirkmaat, 2008; Traithepchanapai, 2016). In all spheres of human relationship, whether in social or legal life, human identification has an indispensable role. It is through the process of identification that it becomes possible to establish an identity for an individual.

The forensic anthropological examination consists of several steps with a common objective to provide information about the biological profile and to identify possible individualizing characteristics and traumatic injuries that can corroborate for a positive identification. The biological profile is defined as the diagnosis of the sex, estimation of the age at the time of death, estimation of the stature and diagnosis of the population affinities through the analysis of the human remains. This biological information is of paramount importance for the identification process as they limit the groups of potential suspects excluding all profiles that do match with the outline. In the human identification, one of the main characteristics in the delineation of the biological profile is the estimation of the sex. In cases of the presence of complete skeletons, sexual dimorphism presents no major difficulties for the observer. However, in cases of fragmented or incomplete skeletons, sexing is considered a challenge. After the pelvis, the skull remains one of the parts of the human skeleton that presents the greatest amount of information in this respect (Kranioti, 2008).

In this context, several studies have been demonstrated that several anatomical regions can be used (Cattaneo, 2007; Dirkmaat, 2008; Traithepchanapai, 2016; Kranioti, 2008; Franklin, 2013; Galdames, 2009; Kanchan, 2013 ; Saini, 2011 and 2012) and some of them are more accurate than others in sexing the skull. This precision has been discussed in some countries, 
however in Brazil; recent studies are concerned with the characteristics of the national population and a way in which the anatomy of the skull can influence these measurements. With a large miscegenation of the population, a question of estimating sex with forensic purposes by means of anatomical characters becomes even more important, since the parameters of other countries cannot be valid for the country. Due to migratory processes, such as geographical, cultural, climatic variations and interaction with the environment, each one develops a distinct anthropometric profile, for this reason it becomes necessary to study different populations (Konigsberg, 2009; Ousley, 2009). The historical migratory flow of Brazil shows that the Brazilian population has very heterogeneous physical characteristics compared to other countries around the world.

Genetic studies have shown that the Brazilian population has a heterogenic profile, with Europeans (77\%) contributing the most, followed by blacks (14\%) and indigenous (8\%) (Pena, 2011; de Moura, 2015). The Southeast region has the highest percentage of European influence (77\%), the Northeast region has the largest African contribution (27\%) and the North has the highest percentage of indigenous contribution (32\%) (de Moura et al., 2015). The Brazilian population according to genetic studies cannot be considered a unit in terms of diversity. The multiplicity of the Brazilian population considering race, region and genetic ancestry should be considered in the study of this population, except when analyzed individually (Kent, 2014). Due to the population-specificity of sexing standards, the present study aimed to conduct a comprehensive statistical analysis of cranial measurements for estimation of sex in a contemporary Brazilian population.

\section{Methodology}

The study sample consisted of 100 skulls, 53 female and 47 males, belonging to the collection of the Institute of Teaching and Research in Forensic Sciences (IEPCF). The collection used in this study is considered modern as the skulls are from the 20th century. The average age was 57.03 years, with a minimum of 18 and a maximum of 104 (Table 1). The inclusion criteria adopted for this research were absence of extensive fractures and skulls belonging to individuals older than 18 years. Exclusion criteria were trauma and extensive fractures. The skulls were exhumed from the Necrópole Campo Santo cemetery located in the city of Guarulhos-Brazil. This is a documented collection, once all the personal information, such as sex, age, statute, ancestry, place of birth and death and date of birth and death were obtained from the public cemetery records. The skulls were cleaned and stored in cardboard boxes and properly identified with a collection number.

Table 1. Descriptive age analysis of the study sample.

\begin{tabular}{|c|c|c|c|c|c|c|c|c|}
\hline Sex & $\mathrm{n}$ & Mean & SD & $95 \%$ & IC & Median & Minimum & Maximum \\
\hline Male $\widehat{\partial}$ & 53 & 54.15 & 18.95 & 8.93 & 59.38 & 56 & 18 & 97 \\
\hline Female $q$ & 47 & 60.28 & 18.89 & 54.73 & 65.82 & 61 & 20 & 104 \\
\hline Total $\widehat{\jmath}$ 우 & 100 & 57.03 & 19.07 & 53.24 & 60.82 & 57.5 & 18 & 104 \\
\hline
\end{tabular}

Source: Authors.

A sequence of measurements of the skulls was performed based on craniometric parameters, and the findings were compared with the sex records of the collections. The measurement protocol was based on 29 cranial landmarks and 51 measurements. Landmarks and measurements are defined in Table 2 and 3. The median sagittal plane and the Frankfurt plan were adopted as reference for standardization of the measures. The positioning of the skulls was performed through the Skull Stabilizer (Figure 1). This device allows alignment of the reference planes through a rectilinear laser beam coupled to the equipment. The skull stabilizer patent was registered in 2012 under number P.I. 1.103.246-4. Measurements were performed directly on the skulls, using a Digital Caliper (Lee Tools, Houston, Texas, USA) with error margin of $0.01 \mathrm{~mm}$, a curved compass and a protractor as described in Table 2. The linear measurements were taken in millimeters (mm) and the angular in 
Research, Society and Development, v. 10, n. 10, e266101018760, 2021

(CC BY 4.0) | ISSN 2525-3409 | DOI: http://dx.doi.org/10.33448/rsd-v10i10.18760

degrees $\left({ }^{\circ}\right)$.

Figure 1. Skull Stabilizer.

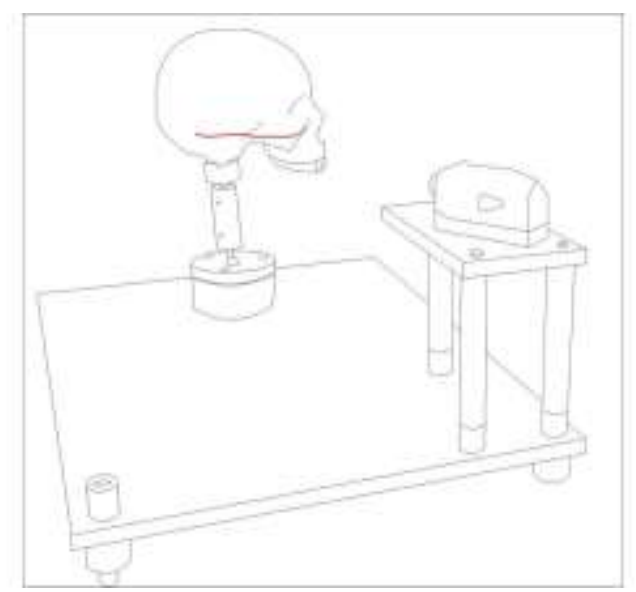

Source: Authors. 
Research, Society and Development, v. 10, n. 10, e266101018760, 2021

(CC BY 4.0) | ISSN 2525-3409 | DOI: http://dx.doi.org/10.33448/rsd-v10i10.18760

Table 2. Definition of landmarks used in the present study.

\begin{tabular}{|c|c|}
\hline Landmark & Definition \\
\hline Alare (al) & Instrumentally determined as the most lateral points on the nasal aperture in a transverse plane. \\
\hline Alveolon (alv) & $\begin{array}{l}\text { The point where the mid-sagittal plane of the palate is intersected by a line connecting the posterior } \\
\text { borders of the alveolar crests. }\end{array}$ \\
\hline Asterion (ast) & The point where the temporal, parietal, and occipital bones meet \\
\hline Bregma $(b)$ & The posterior border of the frontal bone in the midsagittal plane. \\
\hline Basion (ba) & The point at which the anterior border of the foramen magnum is intersected by the mid-sagittal plane. \\
\hline Dacryon $(d)$ & The point on the frontal bone where the frontal, lacrimal and maxillary sutures meet. \\
\hline Ectoconchion (ec) & $\begin{array}{l}\text { The intersection of the most anterior edge of the lateral orbital border and a line parallel to the superior } \\
\text { orbital border that bisects the orbit into two equal halves. }\end{array}$ \\
\hline Ectomolare (ecm) & The most lateral point on the buccal surface of the alveolar process at the level of the second molar. \\
\hline Endomolare (enm) & The point on the lingual surface of the alveolar process at the level of the second molar. \\
\hline Euryon (eu) & The most laterally positioned point on the side of the braincase. \\
\hline Frontomalare temporale (fmt) & The most laterally positioned point on the fronto-malar suture. \\
\hline Frontotemporale $(f t)$ & $\begin{array}{l}\text { The point located generally forward and inward on the superior temporal line directly above the } \\
\text { zygomatic process of the frontal bone. }\end{array}$ \\
\hline Glabella $(g)$ & $\begin{array}{l}\text { The most anteriorly projecting point in the mid-sagittal plane at the lower margin of the frontal bone, } \\
\text { which lies above the nasal root and between the superciliary arches. }\end{array}$ \\
\hline Inion $(i)$ & The point at the junction of the upper nuchal lines with the mid-sagittal plane. \\
\hline $\operatorname{Lambda}(l)$ & The apex of the occipital bone at its junction with the parietals, in the midline. \\
\hline Mastoideale (ms) & The most inferior point on the tip of the mastoid process. \\
\hline Maxillofrontale $(\mathrm{mf})$ & $\begin{array}{l}\text { The point where the anterior lacrimal crest (on the medial border of the orbit) and frontolacrimal suture } \\
\text { intersect. }\end{array}$ \\
\hline Nasion $(n)$ & The point of intersection of the naso-frontal suture and the midsagittal plane. \\
\hline Nasospinale (ns) & $\begin{array}{l}\text { The point where a line drawn between the inferiormost points of the nasal aperture crosses the } \\
\text { midsagittal plane. }\end{array}$ \\
\hline Opisthocranion (op) & The most distant point posteriorly from glabella on the occipital bone, located in the mid-sagittal plane \\
\hline Opisthion $(o)$ & The point on the inner border of the posterior margin of the foramen magnum in the mid-sagittal plane. \\
\hline Orale $(o l)$ & $\begin{array}{l}\text { The most anterior point of hard palate where a line drawn lingual to the central incisors intersects the } \\
\text { palatal suture }\end{array}$ \\
\hline Porion (po) & The most superior point along the upper margin of the external acoustic meatus. \\
\hline Prosthion (pr) & $\begin{array}{l}\text { The most anterior point on the alveolar border of the maxilla between the central incisors in the mid- } \\
\text { sagittal plane. }\end{array}$ \\
\hline Radiculare (ra) & $\begin{array}{l}\text { The point located in the deepest curvature of the root of the zygomatic process at the temporal bone in } \\
\text { a lateral view. }\end{array}$ \\
\hline Staphylion (sta) & The midpoint on the tangent line to the posterior concavities of the hard palate. \\
\hline Zygion (zy) & The most laterally positioned point on the zygomatic arches. \\
\hline Zygomaxillare anterior (zma) & The intersection of the zygomaxillary suture and the limit of the attachment of the masseter muscle. \\
\hline Zygoorbitale (zo) & The intersection of the orbital margin and the zygomaxillary suture. \\
\hline
\end{tabular}

Source: Authors. 
Table 3. Definition of the protocol measurement used in the study.

\begin{tabular}{|c|c|}
\hline Measure & Definition \\
\hline Frontal Angle (FRA) ${ }^{\mathrm{a}}$ & $\begin{array}{l}\text { The angle formed by underlying the frontal curvature at its maximum height } \\
\text { and above the front cord at mid sagittal plane. }\end{array}$ \\
\hline Maximum Cranial Length $(\mathrm{GOL})^{\mathrm{b}}$ & $\begin{array}{l}\text { Linear distance from glabella }(\mathrm{g}) \text { to opisthocranion }(\mathrm{op}) \text { in the mid-sagittal } \\
\text { plane. }\end{array}$ \\
\hline Maximum Cranial Breadth $(\mathrm{XCB})^{\mathrm{b}}$ & Linear distance between right and left euryon (eu). \\
\hline Basion-Bregma Height $(\mathrm{BBH})^{\mathrm{b}}$ & Linear distance from basion (ba) to bregma (b). \\
\hline Cranial Base Length (BNL) ${ }^{\mathrm{b}}$ & Linear distance from basion (ba) to nasion (n). \\
\hline Basion-Prosthion Length $(\mathrm{BPL})^{\mathrm{c}}$ & Linear distance from basion (ba) to prosthion (pr). \\
\hline${\text { Frontal Chord }(\mathrm{FRC})^{\mathrm{c}}}$ & Linear distance from nasion (n) to bregma (b). \\
\hline Parietal Chord (PAC) ${ }^{\mathrm{c}}$ & Linear distance from bregma (b) to lambda (1). \\
\hline${\text { Upper Facial Breadth (UFB) }{ }^{c}}^{c}$ & Linear distance between right and left frontomalare temporale (fmt). \\
\hline${\text { Upper Facial Height }(\mathrm{NPH})^{\mathrm{c}}}^{\mathrm{c}}$ & Linear distance from nasion (n) to prosthion (pr). \\
\hline Minimun Frontal Breadth $(\text { WFB })^{c}$ & Linear distance between right and left frontotemporale (ft). \\
\hline Orbital Breadth $(\mathrm{OBB})^{\mathrm{c}}$ & Linear distance from dacryon (d) to ectoconchion $(\mathrm{ec})$. \\
\hline Orbital Height $(\mathrm{OBH})^{\mathrm{c}}$ & $\begin{array}{l}\text { Linear distance from the superior orbital border to the inferior orbital border } \\
\text { while perpendicular to the natural horizontal axis of the orbit. }\end{array}$ \\
\hline${\text { Zygoorbitale Breadth }(\mathrm{ZOB})^{\mathrm{c}}}^{\mathrm{c}}$ & Linear distance between right and left zygoorbitale (zo). \\
\hline Interorbital Breadth $(\mathrm{DKB})^{\mathrm{c}}$ & Linear distance between right and left dacryon (d). \\
\hline Biorbital Breadth $(\mathrm{EKB})^{\mathrm{c}}$ & Linear distance between right and left ectoconchion $(\mathrm{ec})$. \\
\hline${\text { Frontal Interorbital Breadth }(\mathrm{IOB})^{\mathrm{c}}}^{\mathrm{c}}$ & Linear distance between right and left maxillofrontale (mf). \\
\hline Nasal Height $(\mathrm{NLH})^{\mathrm{c}}$ & Linear disatnce from nasion (n) to nasospinale (ns). \\
\hline Nasal Breadth (NLB) ${ }^{\mathrm{c}}$ & Linear distance between right and left alare (al). \\
\hline Bizygomatica Breadth $(\mathrm{ZYB})^{\mathrm{c}}$ & Linear distance between right and left zygion (zy). \\
\hline Bimaxillary Breadth $(\mathrm{ZMB})^{\mathrm{c}}$ & Linear distance between right and left zygomaxillare anterior (zma). \\
\hline Minimum Vertical Arch (IML) ${ }^{\mathrm{c}}$ & $\begin{array}{l}\text { Linear distance from frontomalare temporale (fmt) to zygomaxillare anterior } \\
\text { (zma). }\end{array}$ \\
\hline Malar length, maximum $(\mathrm{XML})^{\mathrm{c}}$ & $\begin{array}{l}\text { Linear distance from zygoorbitale (zo) to the most inferior lateral point of the } \\
\text { zygomaticotemporal suture. }\end{array}$ \\
\hline Zygoorbitale-Porion Length (ZPL) & Linear distance from zygoorbitale (zo) to porion (po). \\
\hline Asterion-Porion Length (APL) ${ }^{c}$ & Linear distance from asterion (ast) to porion (po). \\
\hline Porion-Mastoidale Length $(\mathrm{PML})^{\mathrm{c}}$ & Linear distance from porion (po) to mastoideale (ms). \\
\hline Asterion-Mastoidale Length $(\mathrm{AML})^{\mathrm{c}}$ & Linear distance from mastoideale (ms) to asterion (ast). \\
\hline Mastoid Length $(\mathrm{MDH})^{\mathrm{c}}$ & $\begin{array}{l}\text { Vertical projection of the mastoid process below and perpendicular to the } \\
\text { Frankfurt plane }\end{array}$ \\
\hline Biauricular Breadth (AUB) ${ }^{\mathrm{c}}$ & Linear distance between right and left radiculare (ra). \\
\hline 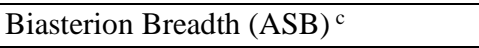 & Linear distance between right and left asterion (ast). \\
\hline Occiptal Chord $(\mathrm{OCC})^{\mathrm{c}}$ & Linear disnatce from lambda (1) to opisthion (o). \\
\hline${\text { Lambda-Inion Chord }(\mathrm{LIC})^{\mathrm{c}}}^{\mathrm{c}}$ & Linear distance from lambda (1) to inion (i). \\
\hline $\begin{array}{l}\text { Maximum length of Occipital } \\
\text { Condyle (MLC) }\end{array}$ & Maximum linear distance from the length of the occipital condyle. \\
\hline $\begin{array}{l}\text { Maximun width of Occipital } \\
\text { Condyle (MWC) }\end{array}$ & Maximum linear distance from the width of the occipital condyle. \\
\hline Foramen Magnum Length $(\mathrm{FOL})^{\mathrm{c}}$ & Linear distance from basion (ba) to opisthion (o). \\
\hline Foramen Magnum Breadth (FOB) & $\begin{array}{l}\text { Distance between the lateral margins of the foramen magnum at the point of } \\
\text { greatest lateral curvature. }\end{array}$ \\
\hline Palatal Breadth $(\mathrm{PAB})^{\mathrm{c}}$ & Linear distance between right and left endomolare (enm). \\
\hline Palatal Length $(\mathrm{PAL})^{\mathrm{c}}$ & Linear distance from orale(ol) to staphylion (sta). \\
\hline Maxillo-Alveolar Breadth (MAB) ${ }^{\mathrm{c}}$ & Linear distance between right and left ectomolare (ecm). \\
\hline Maxillo-Alveolar Length (MAL) ${ }^{\mathrm{c}}$ & Linear distance from prosthion (pr) to alveolon (alv). \\
\hline
\end{tabular}

Source: Authors.

The inter-observer and intra-observer concordance tests were performed by using the intraclass correlation coefficient (ICC) and aiming to verify the reproducibility of the methodology used in the present study. The inter-observer analysis was 
performed by two observers in 20 skulls. The protocols were applied independently and at different times. The intra-observer agreement was tested applying the measurement protocol only by an observer in 20 skulls at distinct times with a one-month interval between measurements. The selection of the skulls to the concordance tests was performed in a random way, that is, the cranium used in the inter-observer analysis were not the same as those used in the intra-observer analysis. The observer did not have access to the sex records of the collection. After the concordance analysis described previously, only one observer of the study performed the application of the measurement protocol in the entire sample.

The statistical analysis was performed in SPSS 22.0, STATA 13.0 and MedCalc, with a significance level of 5\%. The Skewness/Kurtosis normality test was applied, followed by mean and median analysis, paired test $\mathrm{t}$ and Wilcoxon. The receiver operator curves (ROC) and discriminant analysis were applied to the two samples to analyze the sexual dimorphism and the percentage of accuracy for each measure. In addition, the sexual bias of the classification accuracy was described, sexual bias is described as the difference between the male classification accuracy and the female, the greater the sexual bias, the greater is the difference between the two sexes.

In order to sexing the skull, we start from a presupposition that at random we have a percentage of hit of at least 50\%, since we have a dichotomous variable, that is, in the analysis of a skull for estimation of sex this has a $50 \%$ chance of being Female and 50\% chance of being male. Therefore, we consider that a percentage of correct fit for sex estimation would be $25 \%$ above the random percentage, ie, greater than $75 \%$. A multivariate discriminant analysis was applied using the variables that showed accuracy higher or equal to $75 \%$.

In the reference tables, only the measurements with the highest sexual dimorphism were considered. For the elaboration of the tables, 70\%, 80\%, 90\% and 95\% accuracy percentages were considered for each sex (female and male). In addition, the determination point was calculated using the arithmetic mean of the male and female mean values for each variable (Saini, 2011).

The discriminant functions and the reference table were validated in an adult Brazilian sample of 200 computed tomography (100 male and 100 female) from a medical archive. The same inclusion and exclusion criteria were applied. The measurements were performed using the caliper tool in the Invesalius software.

This investigation is on accordance with the international and national parameters of ethics investigation with human beings; the investigation protocol was submitted and approved by the Ethics Committee of the University of São Paulo's School of Dentistry (FOUSP), process number 1.556 .080 and 2.009.550.

\section{Results and Discussion}

Interobserver and intraobserver analysis did not showed statistically significant differences and the ICC varied from good to excellent $(0.60>$ ICC <1.0) except for the measurements of foramen magnum length (FOL) and breadth (FOB) and palatal breadth $(\mathrm{PAB})$ that presented a moderate correlation $(\mathrm{ICC}<0.59)$.

In the measurement protocol used in this study, 11 measurements were performed bilaterally. To analyze the variability between the sides, the test $t$ and Wilcoxon were applied. The values of orbital height $(\mathrm{OBH})$, Porion-Mastoidale length (PML), mastoid length (MDH) presented a difference between the right and left side ( $\mathrm{p}<0.05)$ (Table 4). 
Table 4. Descriptive analysis of the variability between the right and left side.

\begin{tabular}{|c|c|c|c|c|c|c|c|c|c|c|c|c|c|}
\hline \multirow[b]{2}{*}{ Measure } & \multicolumn{5}{|c|}{ Right Side } & \multicolumn{5}{|c|}{ Left Side } & \multirow[b]{2}{*}{$t$} & \multirow{2}{*}{$\begin{array}{c}\text { Test } t \\
p- \\
\text { value }\end{array}$} & \multirow{2}{*}{$\begin{array}{c}\text { Wilcox } \\
\text { on } p \text { - } \\
\text { value }\end{array}$} \\
\hline & $\begin{array}{c}\text { Media } \\
\mathrm{n}\end{array}$ & Mean & $\mathrm{SD}^{\mathrm{a}}$ & $95 \%$ & $\mathrm{CI}^{\mathrm{b}}$ & $\begin{array}{c}\text { Media } \\
\mathrm{n}\end{array}$ & Mean & $\mathrm{SD}^{\mathrm{a}}$ & $95 \%$ & $\mathrm{CI}^{\mathrm{b}}$ & & & \\
\hline OBB & 39.24 & 39.29 & 2.17 & 38.85 & 39.73 & 38.94 & 39.01 & 1.92 & 38.62 & 39.40 & 1.60 & 0.1113 & 0.1369 \\
\hline $\mathrm{OBH}$ & 34.25 & 34.15 & 2.56 & 33.63 & 34.67 & 34.03 & 34.51 & 2.50 & 34.00 & 35.01 & -2.77 & $\begin{array}{c}0.0066 \\
*\end{array}$ & $0.0003 *$ \\
\hline IML & 44.85 & 45.00 & 4.25 & 44.13 & 45.88 & 45.02 & 44.68 & 3.80 & 43.90 & 45.46 & 1.14 & 0.2548 & 0.2290 \\
\hline XML & 49.38 & 49.89 & 6.05 & 48.58 & 51.20 & 50.60 & 50.15 & 6.54 & 48.96 & 51.34 & -0.65 & 0.5151 & 0.4805 \\
\hline $\mathrm{ZPL}$ & 81.40 & 81.94 & 4.78 & 80.96 & 82.92 & 82.02 & 82.15 & 5.02 & 81.13 & 83.17 & -0.73 & 0.4635 & 0.5268 \\
\hline APL & 48.26 & 47.99 & 3.97 & 47.21 & 48.78 & 48.23 & 48.10 & 4.30 & 47.25 & 48.96 & -0.28 & 0.7735 & 0.9301 \\
\hline PML & 29.88 & 29.97 & 3.45 & 29.28 & 30.65 & 31.13 & 31.18 & 3.47 & 30.49 & 31.87 & -5.27 & $\begin{array}{c}0.0001 \\
*\end{array}$ & $0.0001 *$ \\
\hline AML & 49.84 & 50.34 & 5.36 & 49.27 & 51.40 & 50.26 & 50.64 & 5.26 & 49.60 & 51.69 & -0.79 & 0.4280 & 0.4863 \\
\hline $\mathrm{MDH}$ & 28.22 & 27.87 & 3.65 & 27.15 & 28.60 & 29.52 & 28.67 & 3.58 & 27.96 & 29.38 & -3.50 & $\begin{array}{c}0.0007 \\
*\end{array}$ & $0.0002 *$ \\
\hline MLC & 21.93 & 22.35 & 2.69 & 21.79 & 22.90 & 21.89 & 22.21 & 2.78 & 21.64 & 22.78 & 0.68 & 0.4962 & 0.6076 \\
\hline MWC & 11.10 & 11.10 & 1.75 & 10.74 & 11.47 & 11.08 & 11.08 & 1.64 & 10.74 & 11.42 & 0.17 & 0.8633 & 0.6931 \\
\hline HMB & 25.80 & 24.74 & 5.58 & 23.63 & 25.85 & 25.95 & 24.72 & 5.67 & 23.59 & 25.84 & 0.10 & 0.9142 & 0.9849 \\
\hline BMB & 10.38 & 10.43 & 1.80 & 10.08 & 10.79 & 10.06 & 10.29 & 1.94 & 9.90 & 10.67 & 1.51 & 0.1327 & 0.2089 \\
\hline MNB & 32.52 & 32.54 & 3.31 & 31.86 & 33.21 & 32.44 & 32.66 & 3.59 & 31.93 & 33.39 & -0.45 & 0.6534 & 0.4423 \\
\hline MRH & 57.81 & 57.68 & 6.51 & 56.35 & 59.01 & 56.86 & 56.85 & 6.18 & 55.59 & 58.11 & 2.80 & $\begin{array}{c}0.0062 \\
*\end{array}$ & $0.0008^{*}$ \\
\hline MA & 122.00 & 121.94 & 7.39 & 120.47 & 123.41 & 123.00 & 122.55 & 7.87 & 120.59 & 123.71 & -0.50 & 0.6144 & 0.6814 \\
\hline MND & 13.19 & 13.19 & 1.98 & 12.78 & 13.61 & 13.34 & 13.13 & 2.21 & 12.67 & 13.59 & 0.46 & 0.6431 & 0.9472 \\
\hline
\end{tabular}

Source: Authors.

The univariate comparison of cranial measurements showed a higher mean for male skulls, apart from the following variables: Zygoorbital breadth (ZOB), interorbital breadth (DKB), nasal breadth (NLB) and palatal breadth (PAB). The variables maximum cranial breadth (XCB), right and left orbital breadth (OBB), zygoorbitale breadth (ZOB), interorbital breadth (DKB), biorbital breadth (EKB), interorbital breadth (IOB), nasal breadth (NLB), right and left minimum vertical arch (IML) and palatal length (PAL) did not present significant difference between the sexes. The paired test $t$ analysis showed that the variables with the highest sexual dimorphism were maximum cranial length (GOL), Basion-Bregma height (BBH), cranial base length (BNL), nasal height (NLH), bizigomatic breadth (ZYB), upper facial height (NPH), right and left PorionMastoidale length (PML), right and left Asterion-Mastoidale length (AML), right and left mastoid length (MDH), Occipital cord (OCC), right and left maximum length of occipital condyle (MLC). The sexual difference explains 11.42-36.88\% of the sample variance (Table 5). 
Research, Society and Development, v. 10, n. 10, e266101018760, 2021

(CC BY 4.0) | ISSN 2525-3409 | DOI: http://dx.doi.org/10.33448/rsd-v10i10.18760

Table 5. Descriptive statistics and comparison of mean for sexual dimorphism.

\begin{tabular}{|c|c|c|c|c|c|c|c|c|c|c|c|}
\hline \multirow{3}{*}{$\begin{array}{l}\text { Measure } \\
\text { FRA }\end{array}$} & \multicolumn{4}{|c|}{ Male } & \multicolumn{4}{|c|}{ Female } & & \multirow{2}{*}{$R^{2}$} & \multirow{2}{*}{$p$-value } \\
\hline & Mean & $\mathrm{SD}^{\mathrm{a}}$ & & & Mean & $\overline{S D^{a}}$ & & & & & \\
\hline & 97.04 & 2.82 & 96.26 & 97.83 & 95.75 & 2.34 & 95.06 & 96.44 & 2.46 & 0.0590 & 0.0154* \\
\hline GOL & 180.50 & 6.84 & 178.61 & 182.38 & 172.04 & 7.04 & 169.97 & 174.10 & 6.08 & 0.2743 & $0.0001^{*}$ \\
\hline XCB & 134.21 & 7.78 & 132.04 & 136.37 & 132.84 & 7.65 & 130.59 & 135.08 & 0.88 & 0.0080 & 0.3800 \\
\hline BBH & 135.49 & 7.15 & 133.51 & 137.46 & 127.15 & 6.54 & 125.23 & 129.08 & 6.04 & 0.2718 & $0.0001^{*}$ \\
\hline BNL & 100.99 & 4.59 & 99.72 & 102.25 & 94.48 & 4.52 & 93.15 & 95.81 & 7.11 & 0.3405 & $0.0001^{*}$ \\
\hline BPL & 94.97 & 8.29 & 92.64 & 97.30 & 91.02 & 5.38 & 89.40 & 92.64 & 2.72 & 0.0732 & $0.0077^{*}$ \\
\hline FRC & 112.39 & 4.94 & 111.01 & 113.78 & 108.01 & 4.35 & 106.69 & 109.34 & 4.55 & 0.1821 & $0.0001^{*}$ \\
\hline PAC & 112.95 & 6.69 & 111.10 & 114.79 & 108.24 & 6.89 & 106.21 & 110.26 & 3.45 & 0.1088 & $0.0008^{*}$ \\
\hline UFB & 104.15 & 4.40 & 102.93 & 105.36 & 101.42 & 4.43 & 100.10 & 102.73 & 3.06 & 0.0884 & $0.0028^{*}$ \\
\hline $\mathrm{NPH}$ & 65.90 & 6.35 & 64.11 & 67.69 & 60.37 & 4.99 & 58.87 & 61.87 & 4.69 & 0.1900 & $0.0001 *$ \\
\hline WFB & 98.43 & 4.63 & 97.16 & 99.71 & 96.25 & 4.49 & 94.93 & 97.57 & 0.01 & 0.0548 & $0.0190 *$ \\
\hline OBBd & 39.84 & 2.25 & 39.22 & 40.46 & 38.67 & 1.85 & 38.11 & 39.22 & 2.78 & 0.0748 & $0.0064^{*}$ \\
\hline OBBe & 39.33 & 1.91 & 38.79 & 39.87 & 38.65 & 1.84 & 38.11 & 39.19 & 1.79 & 0.0326 & 0.0754 \\
\hline OBHd & 34.55 & 2.66 & 33.82 & 35.29 & 33.61 & 2.37 & 32.90 & 34.31 & 1.84 & 0.0340 & 0.0675 \\
\hline $\mathrm{OBHe}$ & 35.01 & 2.56 & 34.28 & 35.73 & 33.93 & 2.32 & 33.25 & 34.61 & 2.16 & 0.0467 & $0.0326^{*}$ \\
\hline $\mathrm{ZOB}$ & 55.82 & 4.92 & 54.42 & 57.22 & 58.04 & 7.71 & 55.75 & 60.33 & -1.69 & 0.0296 & 0.0938 \\
\hline$\overline{D K B}$ & 20.60 & 2.68 & 19.86 & 21.34 & 21.33 & 2.40 & 20.61 & 22.04 & -1.40 & 0.0201 & 0.1619 \\
\hline EKB & 97.55 & 4.26 & 96.35 & 98.75 & 96.07 & 3.89 & 94.90 & 97.24 & 1.76 & 0.0320 & 0.0812 \\
\hline IOB & 12.77 & 2.24 & 12.15 & 13.39 & 12.35 & 2.60 & 11.58 & 13.11 & 0.87 & 0.0078 & 0.3831 \\
\hline NLH & 51.17 & 2.70 & 50.41 & 51.93 & 47.24 & 3.42 & 46.21 & 48.27 & 6.28 & 0.2958 & $0.0001^{*}$ \\
\hline NLB & 24.33 & 2.26 & 23.70 & 24.97 & 24.53 & 2.02 & 23.92 & 25.14 & -0.44 & 0.0021 & 0.6546 \\
\hline ZYB & 128.23 & 5.50 & 126.58 & 129.89 & 121.02 & 4.31 & 119.69 & 122.35 & 6.81 & 0.3508 & $0.0001^{*}$ \\
\hline ZMB & 91.04 & 5.21 & 89.57 & 92.51 & 87.59 & 6.37 & 85.67 & 89.50 & 2.91 & 0.0831 & $0.0044 *$ \\
\hline IMLd & 45.27 & 4.96 & 43.89 & 46.66 & 44.64 & 3.12 & 43.68 & 45.59 & 0.73 & 0.0058 & 0.4618 \\
\hline IMLe & 45.10 & 4.49 & 43.84 & 46.37 & 44.03 & 2.64 & 43.22 & 44.83 & 1.42 & 0.0206 & 0.1588 \\
\hline XMLd & 50.80 & 5.76 & 49.13 & 52.47 & $\begin{array}{ll}48.48 \\
\end{array}$ & 5.99 & 46.66 & 50.30 & 1.88 & 0.0382 & 0.0620 \\
\hline XMLe & 51.65 & 4.87 & 50.21 & $\begin{array}{l}53.08 \\
\end{array}$ & 48.52 & 5.53 & 46.84 & 50.20 & 2.86 & 0.0843 & $0.0052^{*}$ \\
\hline ZPLd & 83.96 & 5.02 & 82.54 & 85.37 & 79.69 & 3.22 & 78.72 & 80.66 & 4.87 & 0.2018 & $0.0001 *$ \\
\hline ZPLe & 83.91 & 5.25 & 82.43 & 85.39 & 80.21 & 3.84 & \begin{tabular}{|l|}
79.08 \\
\end{tabular} & 81.34 & 3.94 & 0.1397 & $0.0002 *$ \\
\hline APLd & 499.57 & 3.52 & 48.60 & 50.54 & 46.22 & 3.72 & 45.13 & 47.32 & 4.60 & 0.1782 & $0.0001 *$ \\
\hline APLe & 49.80 & 3.81 & 48.75 & 50.85 & 46.18 & 4.04 & 45.00 & 47.37 & 4.60 & 0.1779 & $0.0001^{*}$ \\
\hline PMLd & 31.63 & 3.09 & 30.78 & 32.49 & 28.09 & 2.83 & 27.26 & 28.92 & 5.94 & 0.2648 & $0.0001 *$ \\
\hline PMLe & 32.96 & 2.93 & 32.15 & 33.76 & 29.17 & 2.91 & 28.31 & 30.02 & 6.46 & 0.2989 & $0.0001 *$ \\
\hline AMLd & 52.85 & 4.89 & 51.50 & $\begin{array}{l}54.20 \\
\end{array}$ & 47.50 & 4.40 & 46.20 & 48.79 & 5.72 & 0.2506 & $0.0001^{*}$ \\
\hline AMLe & 53.19 & 4.66 & 51.90 & 54.47 & 47.77 & 4.38 & 46.49 & 49.06 & 5.95 & 0.2660 & $0.0001^{*}$ \\
\hline MDHd & 29.69 & 3.26 & 28.79 & 30.59 & 25.83 & 2.93 & 24.97 & 26.69 & 6.18 & 0.2809 & $0.0001^{*}$ \\
\hline MDHe & 30.71 & 2.75 & 29.95 & 31.47 & 26.37 & 2.98 & 25.49 & 27.25 & 7.56 & 0.3688 & $0.0001^{*}$ \\
\hline AUB & 122.54 & 4.96 & 121.18 & 123.91 & 117.79 & 3.77 & 116.68 & 118.90 & 5.33 & 0.2252 & $0.0001 *$ \\
\hline ASB & 112.12 & 6.20 & 110.41 & 113.83 & 108.76 & 5.75 & 107.07 & 110.45 & 2.79 & 0.0738 & $0.0063^{*}$ \\
\hline OCC & 97.36 & 5.55 & 95.83 & 98.89 & 93.51 & 5.43 & 91.91 & 95.11 & 3.49 & 0.1108 & $0.0007^{*}$ \\
\hline LIC & 68.54 & 8.62 & 66.14 & 70.94 & $\begin{array}{l}63.67 \\
\end{array}$ & 7.00 & 61.54 & 65.80 & 3.00 & 0.0875 & $0.0034 *$ \\
\hline MLCd & 23.18 & 2.71 & 22.42 & 23.97 & 21.35 & 2.26 & 20.65 & 22.04 & 3.51 & 0.1174 & $0.0007^{*}$ \\
\hline MLCe & 23.03 & 3.11 & 22.16 & 23.90 & 21.15 & 1.85 & 20.57 & 21.73 & 3.44 & 0.1142 & $0.0009^{*}$ \\
\hline MWCd & 11.20 & 1.81 & 10.69 & 11.70 & 11.05 & 1.68 & 10.53 & 11.57 & 0.41 & 0.0019 & 0.6780 \\
\hline MWCe & 11.16 & 1.68 & 10.69 & 11.63 & 11.03 & 1.62 & 10.53 & 11.54 & 0.37 & 0.0008 & 0.7056 \\
\hline FOL & 32.36 & 3.26 & 31.46 & 33.26 & 30.80 & 3.33 & 29.81 & 3.79 & 2.33 & 0.0533 & $0.0215^{*}$ \\
\hline FOB & 33.70 & 3.62 & 32.70 & 34.70 & 32.09 & 3.04 & 31.20 & 32.99 & 2.37 & 0.0546 & 0.0193* \\
\hline PAB & 35.00 & 3.40 & 34.02 & 35.98 & 35.02 & 3.89 & 33.83 & 36.20 & -0.02 & 0.0001 & 0.9829 \\
\hline PAL & 48.01 & 6.11 & 46.23 & 49.78 & 46.50 & 5.69 & 44.73 & 48.27 & 1.20 & 0.0162 & 0.2317 \\
\hline MAB & 58.26 & 6.37 & 56.43 & 60.09 & 55.53 & 4.38 & 54.17 & 56.90 & 2.33 & 0.0577 & $0.0218^{*}$ \\
\hline MAL & 51.89 & 5.70 & 50.21 & 53.56 & 48.95 & 5.54 & 47.56 & 50.35 & 2.68 & 0.0755 & $0.0088^{*}$ \\
\hline
\end{tabular}

${ }^{\text {a }}$ standard deviation

${ }^{\mathrm{b}}$ confidence interval

*statically significant $(\mathrm{p}<0.05)$

Source: Authors. 
Table 6 shows the percentage of correct classification of male and female, as well as the average of this percentage. In order to evaluate sexual dimorphism, Wilks's lambda is also presented in this table, smaller values indicates greater sexual dimorphism and values close to 1.0 indicates lower discriminatory ability.

Table 6. Direct discriminant analysis of the cranial measurements.

\begin{tabular}{|c|c|c|c|c|c|c|c|c|c|c|c|}
\hline Measure & $\begin{array}{l}\text { Lambda } \\
\text { Wilks }\end{array}$ & $\begin{array}{c}\text { Male } \\
\text { Accuracy } \\
(\%)\end{array}$ & $\begin{array}{c}\text { Female } \\
\text { Accuracy } \\
(\%)\end{array}$ & $\begin{array}{c}\text { Mean } \\
\text { Accuracy } \\
(\%)\end{array}$ & $\begin{array}{l}\text { Sex } \\
\text { bias }\end{array}$ & Measure & $\begin{array}{l}\text { Lambda } \\
\text { Wilks }\end{array}$ & $\begin{array}{c}\text { Male } \\
\text { Accuracy } \\
(\%)\end{array}$ & $\begin{array}{c}\text { Female } \\
\text { Accuracy } \\
(\%)\end{array}$ & $\begin{array}{c}\text { Mean } \\
\text { Accuracy } \\
(\%)\end{array}$ & $\begin{array}{l}\text { Sex } \\
\text { bias }\end{array}$ \\
\hline FRA & 0.941 & 58.50 & 53.20 & 56.00 & 5.30 & XMLe & 0.916 & 67.90 & 53.20 & 61.00 & 14.70 \\
\hline GOL & 0.726 & 79.20 & 76.60 & $78.00^{*}$ & 2.60 & ZPLd & 0.798 & 73.60 & 66.00 & 70.00 & 7.60 \\
\hline $\mathrm{XCB}$ & 0.992 & 75.50 & 34.00 & 56.00 & 41.50 & ZPLe & 0.860 & 73.60 & 68.10 & 71.00 & 5.50 \\
\hline BBH & 0.728 & 75.50 & 74.50 & $75.00 *$ & 1.00 & APLd & 0.822 & 83.00 & 66.00 & $75.00 *$ & 17.00 \\
\hline BNL & 0.659 & 84.90 & 70.20 & $78.00^{*}$ & 14.70 & APLe & 0.822 & 73.60 & 63.80 & 69.00 & 9.80 \\
\hline BPL & 0.927 & 58.50 & 57.40 & 58.00 & 1.10 & PMLd & 0.735 & 73.60 & 68.10 & 71.00 & 5.50 \\
\hline FRC & 0.818 & 77.40 & 59.60 & 69.00 & 17.80 & PMLe & 0.701 & 77.40 & 74.50 & $76.00^{*}$ & 2.90 \\
\hline PAC & 0.891 & 69.80 & 51.10 & 61.00 & 18.70 & AMLd & 0.749 & 71.70 & 70.20 & 71.00 & 1.50 \\
\hline UFB & 0.912 & 67.90 & 53.20 & 61.00 & 14.70 & AMLe & 0.734 & 69.80 & 70.20 & 70.00 & -0.40 \\
\hline $\mathrm{NPH}$ & 0.810 & 73.90 & 63.80 & 69.00 & 10.10 & MDHd & 0.719 & 81.10 & 68.10 & $75.00 *$ & 13.00 \\
\hline WFB & 0.945 & 69.80 & 46.80 & 59.00 & 23.00 & MDHe & 0.631 & 84.90 & 78.70 & $82.00 *$ & 6.20 \\
\hline $\mathrm{OBB}^{\mathrm{d}}$ & 0.925 & 75.50 & 46.80 & 62.00 & 28.70 & AUB & 0.775 & 71.70 & 72.30 & 72.00 & -0.60 \\
\hline $\mathrm{OBB}^{\mathrm{e}}$ & 0.967 & 64.20 & 40.40 & 53.00 & 23.80 & ASB & 0.926 & 64.20 & 63.80 & 64.00 & 0.40 \\
\hline $\mathrm{OBH}^{\mathrm{d}}$ & 0.966 & 66.00 & 40.40 & 54.00 & 25.60 & OCC & 0.995 & 81.10 & 21.30 & 53.00 & 59.80 \\
\hline $\mathrm{OBH}^{\mathrm{e}}$ & 0.953 & 58.50 & 57.40 & 58.00 & 1.10 & LIC & 0.913 & 71.70 & 53.20 & 63.00 & 18.50 \\
\hline $\mathrm{ZOB}$ & 0.970 & 75.50 & 44.70 & 61.00 & 30.80 & MLCd & 0.883 & 71.70 & 53.20 & 63.00 & 18.50 \\
\hline DKB & 0.980 & 71.70 & 36.20 & 55.00 & 35.50 & MLCe & 0.886 & 69.80 & 48.90 & 60.00 & 20.90 \\
\hline EKB & 0.968 & 69.80 & 30.20 & 55.00 & 39.60 & MWCd & 0.998 & 100.00 & 0.00 & 53.00 & 100.00 \\
\hline IOB & 0.992 & 77.40 & 27.70 & 54.00 & 49.70 & MWCe & 0.998 & 100.00 & 2.10 & 54.00 & 97.90 \\
\hline NLH & 0.740 & 84.90 & 66.00 & $76.00 *$ & 18.90 & FOL & 0.947 & 66.00 & 44.70 & 56.00 & 21.30 \\
\hline NLB & 0.998 & 92.50 & 8.50 & 53.00 & 84.00 & FOB & 0.945 & 66.00 & 44.70 & 56.00 & 21.30 \\
\hline ZYB & 0.649 & 75.50 & 70.20 & 73.00 & 5.30 & PAB & 1.000 & 100.00 & 0.00 & 53.00 & 100.00 \\
\hline ZMB & 0.917 & 71.70 & 55.30 & 64.00 & 16.40 & PAL & 0.984 & 79.20 & 27.70 & 55.00 & 51.50 \\
\hline IMLd & 0.994 & 90.60 & 2.10 & 49.00 & 88.50 & MAB & 0.942 & 69.80 & 38.30 & 55.00 & 31.50 \\
\hline IMLe & 0.979 & 69.80 & 40.40 & 56.00 & 29.40 & MAL & 0.924 & 67.90 & 57.40 & 63.00 & 10.50 \\
\hline XMLd & 0.962 & 67.90 & 55.30 & 62.00 & 12.60 & & & & & & \\
\hline
\end{tabular}

Source: Authors.

In the univariate discriminant analysis of the 72 cranial and mandibular measurements referring to the Brazilian sample, the percentage of accuracy varied between 49-82\%. Since 08 cranial measurements obtained an average percentage of hit higher than $75 \%$. Wilks' Lambda $(\kappa)$ ranged from 0.631 to 1.0 , the variables that showed the greatest difference between the sexes were the bizigomatic width (ZYB) with a lambda value of 0.631 and the left mastoid length (MDHe) $K=0.649$. The measures that showed the lowest sexual bias were the biasterion breadth (ASB) and left Asterion-Mastoidale length (AMLe).

In the univariate discriminant analysis of the 51 cranial measurements, the percentage of accuracy varied between 49 $82 \%$. Since 08 cranial demonstrated an average percentage of classify correctly higher than $75 \%$. Wilks' Lambda $(K)$ ranged from 0.631 to 1.0 , the variables that showed the greatest difference between the sexes were the bizigomatic breadth (ZYB) 
with a lambda value of 0.631 and the left mastoid length (MDHe) $\kappa=0.649$. The measures that showed the lowest sexual bias were the biasterion breadth (ASB) and left Asterion-Mastoidale length (AMLe).

The bizigomatic breadth (ZYB), although it did not show a mean percentage higher than $75 \%$, was included in the multivariate analysis, since it presented one of the lowest Wilks lambda values $(K=0.649)$, showing a high difference between the sexes. Table 7 shows the multivariate discriminant analysis of the cranial measurements of the Brazilian sample, the percentage of accuracy considering all cranial variables was $90 \%$ and $\Lambda=0.374$. The other functions considering only some of these measures showed a variation of the accuracy of $82-86 \%$.

Table 7. Discriminant equations, group centroids and correct assignment by sex.

\begin{tabular}{|c|c|c|c|c|c|c|c|}
\hline \multirow[b]{2}{*}{$\begin{array}{c}\text { Measure } \\
\text { and Formula }\end{array}$} & \multicolumn{2}{|c|}{ Coefficient } & \multirow{2}{*}{$\begin{array}{c}\text { Group } \\
\text { centroids }\end{array}$} & \multirow{2}{*}{$\begin{array}{l}\text { Lambda } \\
\text { Wilks }\end{array}$} & \multicolumn{3}{|c|}{ Correctly assigned (\%) } \\
\hline & Male & Female & & & Male & Female & Mean \\
\hline GOL & 1.885 & 1.871 & \multirow{10}{*}{$\begin{array}{l}\mathrm{M}=1.248 \\
\mathrm{~F}=-1.308\end{array}$} & \multirow{10}{*}{0.374} & \multirow{10}{*}{88.7} & \multirow{10}{*}{91.5} & \multirow{10}{*}{90} \\
\hline $\mathrm{BBH}$ & 1.140 & 1.153 & & & & & \\
\hline BNL & 1.266 & 1.062 & & & & & \\
\hline NLH & 2.230 & 2.005 & & & & & \\
\hline ZYB & 4.400 & 4.185 & & & & & \\
\hline APLd & 3.139 & 2.924 & & & & & \\
\hline PMLe & -2.340 & -2.258 & & & & & \\
\hline MDHd & 2.478 & 2.222 & & & & & \\
\hline MDHe & -0.375 & -0.63 & & & & & \\
\hline Constant & -721.815 & -640.881 & & & & & \\
\hline
\end{tabular}

$(1.885 * \mathrm{GOL})+(1.140 * \mathrm{BBH})+(1.266 * \mathrm{BNL})+(2.230 * \mathrm{NLH})+(4.400 * \mathrm{ZYB})+(3.139 * \mathrm{APLd})+$

Function 1 $(-2.340 * \mathrm{PMLe})+(2.478 * \mathrm{MDHd})+(-0.375 * \mathrm{MDHe})$

Female $=-640.881+$

$(1.871 * \mathrm{GOL})+(1.153 * \mathrm{BBH})+(1.062 * \mathrm{BNL})+(2.005 * \mathrm{NLH})+(4.185 * \mathrm{ZYB})+(2.924 * \mathrm{APLd})+$

\begin{tabular}{lcccccc} 
& \multicolumn{5}{c}{$(-2.258 * \mathrm{PMLe})+(2.222 * \mathrm{MDHd})+(-0.63 * \mathrm{MDHe})$} \\
\hline GOL & 1.956 & 1.929 & & & & \\
BBH & 1.456 & 1.393 & $\mathrm{M}=1.040$ & 0.463 & 87 & 85 \\
BNL & 1.043 & 0.885 & $\mathrm{~F}=-1.090$ & & & \\
NLH & 1.699 & 1.429 & & & & \\
ZYB & 4.183 & 3.957 & & & \\
Constant & -640.009 & -570.313 & & & & \\
\hline
\end{tabular}

\begin{tabular}{lccccc}
\hline \multirow{2}{*}{ Function 2} & \multicolumn{5}{c}{ Male $=-640.009+(1.956 * \mathrm{GOL})+(1.456 * \mathrm{BBH})+(1.043 * \mathrm{BNL})+(1.699 * \mathrm{NLH})+(4.183 * \mathrm{ZYB})$} \\
& \multicolumn{5}{c}{ Female $=-570.313+(1.929 * \mathrm{GOL})+(1.393 * \mathrm{BBH})+(0.885 * \mathrm{BNL})+(1.429 * \mathrm{NLH})+(3.957 * \mathrm{ZYB})$} \\
\hline APLd & 3.426 & 3.213 & & & \\
PMLe & 1.698 & 1.625 & $\mathrm{M}=0.812$ & 0.568 & 80.9 \\
MDHd & 1.267 & 1.162 & $\mathrm{~F}=-0.916$ & & \\
MDHe & 1.054 & 0.688 & & \\
Constant & -148.535 & -122.793 & & \\
\hline
\end{tabular}

\begin{tabular}{|c|c|c|c|c|c|c|c|}
\hline Constant & -148.535 & -122.793 & & & & & \\
\hline \multirow{2}{*}{ Function 3} & \multicolumn{7}{|c|}{ Male $=-148.535+(3.426 *$ APLd $)+(1.698 *$ PMLe $)+(1.267 * \mathrm{MDHd})+(1.054 * \mathrm{MDHe})$} \\
\hline & \multicolumn{7}{|c|}{ Female $=-122.793+(3.213 *$ APLd $)+(1.625 *$ PMLe $)+(1.162 *$ MDHd $)+(0.877 * \mathrm{MDHe})$} \\
\hline GOL & 2.373 & 2.337 & & \multirow{5}{*}{0.460} & \multirow{5}{*}{86.8} & \multirow{5}{*}{85.1} & \multirow{5}{*}{86} \\
\hline BNL & 2.637 & 2.395 & $\mathrm{M}=1.007$ & & & & \\
\hline NLH & 1.902 & 1.760 & $\mathrm{~F}=-1.142$ & & & & \\
\hline MDHe & 1.682 & 1.209 & & & & & \\
\hline Constant & -422.881 & -372.337 & & & & & \\
\hline \multirow{2}{*}{ Functionn 4} & \multicolumn{7}{|c|}{ Male $=-422.81+(2.373 * \mathrm{GOL})+(2.637 * \mathrm{BNL})+(1.902 * \mathrm{NLH})+(1.682 * \mathrm{MDHe})$} \\
\hline & \multicolumn{7}{|c|}{ Female $=-372.337+(2.337 * \mathrm{GOL})+(2.395 * \mathrm{BNL})+(1.760 * \mathrm{NLH})+(1.209 * \mathrm{MDHe})$} \\
\hline
\end{tabular}

Source: Authors.

Table 8 shows the analysis of the ROC curves for the variables that presented a percentage of accuracy higher than $75 \%$ in the univariate discriminant analysis, adding the bizigomatic width (ZYB). The analysis of the area under the curve 
(AUC) shows that with the exception of the right Asterion-Porion length (APLd) (0.769), all other variables present an ability to estimate correctly sex greater than $80 \%$. The cut-off points presented in the table represent the ideal point for sex discrimination for each variable, with the percentages of accuracy for each sex.

Table 8. ROC curve analysis of cranial measurements.

\begin{tabular}{|c|c|c|c|c|c|c|c|c|c|}
\hline Measure & AUC & $\begin{array}{c}p- \\
\text { value }\end{array}$ & $\begin{array}{c}\text { Lower } \\
\text { Limit }\end{array}$ & $\begin{array}{l}\text { Upper } \\
\text { Limit }\end{array}$ & & Section Pc & & Male $(\%)$ & Female $(\%)$ \\
\hline GOL & 0.818 & $<0.001$ & 0.733 & 0.903 & $q<$ & 172.25 & $>\hat{0}$ & 81.1 & 76.6 \\
\hline $\mathrm{BBH}$ & 0.807 & $<0.001$ & 0.721 & 0.893 & $q<$ & 133.75 & $>0$ & 69.8 & 85.1 \\
\hline BNL & 0.848 & $<0.001$ & 0.773 & 0.923 & $q<$ & 95.75 & $>\hat{0}$ & 92.5 & 66.0 \\
\hline NLH & 0.839 & $<0.001$ & 0.756 & 0.921 & $q<$ & 48.81 & $>\hat{0}$ & 84.3 & 71.1 \\
\hline $\mathrm{ZYB}$ & 0.849 & $<0.001$ & 0.770 & 0.929 & $q<$ & 127.79 & $>\hat{0}$ & 60.0 & 97.7 \\
\hline APLd & 0.769 & $<0.001$ & 0.674 & 0.864 & $q<$ & 48.18 & $>\hat{0}$ & 77.4 & 76.6 \\
\hline PMLe & 0.816 & $<0.001$ & 0.732 & 0.901 & $q<$ & 31.40 & $>0$ & 73.6 & 80.9 \\
\hline MDHd & 0.816 & $<0.001$ & 0.733 & 0.900 & $q<$ & 27.95 & $>\hat{0}$ & 79.2 & 74.5 \\
\hline MDHe & 0.856 & $<0.001$ & 0.783 & 0.930 & $9<$ & 28.31 & $>0$ & 86.8 & 78.7 \\
\hline
\end{tabular}

Source: Authors.

Through the analysis of the ROC curve a table of reference were developed for estimating sex in the Brazilian population (Table 9).

Table 9. ROC curve analysis of cranial measurements.

\begin{tabular}{|c|c|c|c|c|c|c|c|c|c|}
\hline \multirow{2}{*}{ Measure } & \multicolumn{4}{|c|}{ Male } & \multirow{2}{*}{$\begin{array}{l}\text { Determination } \\
\text { Point }\end{array}$} & \multicolumn{4}{|c|}{ Female } \\
\hline & $95 \%$ & $90 \%$ & $80 \%$ & $70 \%$ & & $70 \%$ & $80 \%$ & $90 \%$ & $95 \%$ \\
\hline GOL & 195.50 & 192.00 & 186.00 & 183.50 & 176.27 & 169.00 & 166.50 & 165.00 & 159.00 \\
\hline $\mathrm{BBH}$ & 145.50 & 143.50 & 141.50 & 139.50 & 131.32 & 126.00 & 123.00 & 117.50 & 115.50 \\
\hline BNL & 112.00 & 109.00 & 105.00 & 103.50 & 97.74 & 92.00 & 91.00 & 89.00 & 87.00 \\
\hline NLH & 57.30 & 55.26 & 53.38 & 52.47 & 49.21 & 45.30 & 44.91 & 43.94 & 43.05 \\
\hline ZYB & 137.39 & 134.98 & 133.36 & 131.60 & 124.63 & 118.59 & 117.64 & 115.64 & 114.79 \\
\hline APLd & 57.10 & 54.13 & 52.01 & 51.11 & 47.90 & 45.13 & 44.20 & 42.79 & 42.23 \\
\hline PMLe & 38.83 & 36.73 & 35.34 & 34.77 & 31.07 & 27.80 & 26.97 & 25.66 & 25.00 \\
\hline MDHd & 35.47 & 34.83 & 32.81 & 31.07 & 27.76 & 23.98 & 23.29 & 21.85 & 21.10 \\
\hline $\mathrm{MDHe}$ & 35.47 & 33.78 & 33.30 & 32.29 & 28.54 & 25.00 & 23.64 & 22.68 & 22.30 \\
\hline
\end{tabular}

Source: Authors.

The validation of the discriminant functions showed a percentage of accuracy between 74.2 to 85.7. Function 03 showed the worst mean percentage of correct answers (74.2). The reference table showed an average percentage of correct answers of $79.5 \%, 80 \%$ for females and $79 \%$ for males. 
Table 10. Validation of discriminant function in the computed tomography Brazilian sample.

\begin{tabular}{l|l|l|l}
\hline Function & $\begin{array}{l}\text { Mean } \\
\text { Accuracy }(\%)\end{array}$ & $\begin{array}{l}\text { Male Accuracy } \\
(\%)\end{array}$ & $\begin{array}{l}\text { Female Accuracy } \\
(\%)\end{array}$ \\
\hline Função 1 & 85.7 & 84.4 & 87.2 \\
\hline Função 2 & 80.7 & 78.7 & 82.7 \\
\hline Função 3 & 74.2 & 75.2 & 73.1 \\
\hline Função 4 & 80.1 & 80.9 & 79.2 \\
\hline
\end{tabular}

Source: Authors.

The analysis of the reproducibility and repeatability of a method for human identification using a quantitative method is of paramount importance to ensure that the measures taken follow the same parameter and that the results are faithful to each other. The technique. to be reliable. must be reproducible between the observers and assure the repeatability among several measurements of the same observer.

The protocol applied in this study had several variables. the majority of which presented excellent reproducibility and repeatability. according to the findings demonstrated in the results. Measurements for the foramen magnum presented a moderate ICC for the inter-observer analysis. with the length (FOL) ICC $=0.596$ and the breadth (FOB) ICC $=0.555$. while in the intra-observer analysis the length (FOL) showed a moderate correlation ICC $=0.408$ but the FOB showed a weak correlation ( $\mathrm{ICC}=0.339$ ). evidencing a low reproducibility and repeatability. Contrasting the results found in the present study. Gapert et al. (2009). in a study carried out with 20 skulls belonging to the University College Dublin collection. found satisfactory results regarding the reproducibility and repeatability of the measurements for foramen magnum (length and breadth). Raghavendra Babu et al.(2012). also found no significant differences in the intra-observer and inter-observer analysis of 10 skulls from the Forensic Medicine department of Kasturba Medical College. Mangalore. India. Likewise. the study by Uthman et al.(2012) evaluated 88 tomographic images of the Al-Najaf Teaching Hospital collection for estimating sex by means of measurements of the foramen magnum and did not show statistically significant differences $(p>0.05)$ in the intra and inter-observer analysis. Ilguy et al.(2014). analyzed 161 tomographic images of European descendants. the intra-observer analysis also did not show a difference between the results obtained for the measurements of the foramen magnum. Other authors evaluated the length and breadth of the foramen magnum for sex estimation in several populations. but did not perform inter-observer and/or intra-observer analysis and it is not possible to compare with the present study (Galdames, 2009; Edwards, 2013; Kamath 2015). Palatal breadth (PAB) also showed a moderate ICC (0.454) in the inter-observer analysis and a good correlation in the intra-observer analysis $(\mathrm{ICC}=0.659)$. in contrast to other authors in the literature who reported a good reproducibility and repeatability of this measurement (Franklin, 2013; Dayal, 2008).

Some measures showed a significant difference between the analyzes. but when analyzing the means. medians and intraclass correlation coefficients. we verified that. except for foramen magnum measures (FOB and FOL) and palatal breadth (PAB). all others presented a low difference between the means and medians. and a good to excellent correlation. demonstrating that these variables can be used and that they have a reasonable potential for repeatability and reproducibility. However, the variables need to be evaluated with caution since a statistical difference evidenced mathematically through the pvalue does not always express a considerable difference in forensic practice. therefore, several questions must be analyzed to conclude that a measure really has a low or high level of accuracy in inter- and intra-observer analysis.

The estimation of sex is an extremely important step for the construction of the biological profile. There are several techniques in the literature to assist in this construction. being they qualitative. through the analysis of the morphology of the skull and mandible or quantitative through the metric analysis of the bone structures using linear. angular. areas. perimeters. 
circumference lengths. indices among other analyzes. In this study. it was analyzed only linear and angular measurements of a Brazilian sample to verify which measures have the highest sexual dimorphism.

This study showed that among the 51 analyzed variables. only 09 skull variables presented satisfactory results for sex estimation. being maximum cranial length (GOL). Basion-Bregma height (BBH). cranial base length (BNL). nasal height (NLH). bizigomatic breadth (ZYB). right Asterion-Porion length (APLd). left Porion-Mastoidale length (PMLe) and right (MDHd) and left (MDHe) mastoid length. Among these variables. the length of the left mastoid process (MDHe). the cranial base length (BNL). maximum cranial length (GOL) and bizigomatic breadth (ZYB) presented in the descriptive analysis and the univariate discriminant analysis the highest sexual dimorphism. The results evidenced in our study corroborate with the results reported by previous studies (Franklin, 2005 and 2013; Saini, 2011; Ilguv, 2014; Matamala, 2009; de Oliveira, 2012; Fatah, 2014; Ekizoglu, 2016; Dong, 2015).

The analysis of the averages showed that of the 51 variables. only 04 measures presented a greater average for female skulls: zygoorbitale breadth (ZOB). interorbital breadth (DKB). nasal breadth (NLB) and palatal breadth (PAB). The other measurements presented higher averages for males. The measurements that presented higher averages for the female sex did not present a statistically significant difference to analyze sexual dimorphism; therefore. they are not reliable variables for this type of analysis. Several studies in the literature demonstrate findings in accordance with the results found in this present study (Franklin, 2013; Saini, 2011; Matamala 2009)

The study of specific populations is of great relevance for the development of precise parameters for each region and / or Country. since the regression formulas are sensitive to population changes (Cunha and Van vark, 1991; Inoue, 1992). The present study. using multivariate discriminant analysis. elaborated 04 formulas for the Brazilian population using cranial measurements. The average percentage of correct classify sex varied between 82-90\%. The formula with the highest discriminatory accuracy was the one that encompasses the 09 most dimorphic variables for Brazilian population. presenting a mean percentage of correctness of $90 \%$. An earlier study performed with a Brazilian sample showed a percentage of accuracy using only bi-zygomatic breadth and Basion-Lambda distance of $76 \%$ for the female sex and $68 \%$ males. the results obtained in the present study are slightly higher. however, It is worth noting that an association of a greater number of variables was performed (de Oliveira, 2012).

Several formulas have been developed to allow the use in a greater number of cases around the world. since the absence of a variable that makes up the formula invalidates its use. For example, in cases of fragmented bone structures or in the presence of only a few regions of the skull. The present study developed 04 different formulas with different variables. since in forensic practice the absence of structures for analysis are always a common scenario.

The development of population-specific tables that optimize anthropological analysis and at the same time ensure satisfactory accuracy is extremely relevant to forensic practice. Thus. the present study through the ROC curve analysis developed a reference table for estimating sex in Brazilian population using cranial measurements. The table presents the determination points for each variable. being lower values attributed to females and higher values for males. Besides that, it displays the respective values for each variation of the $70 \% .80 \% .90 \%$ and $95 \%$ percentages of correct classify the sex. The functions and reference tables presented in the present study were developed based on contemporary Brazilian's skulls, considering the population-specificity of the discriminant functions and ROC curve analysis. these should be used only in forensic cases that are known to come from the same century and same population from which this functions and tables were derived in order to obtain similar accuracy (Gapert, 2009).

The validation of these tables and functions in a large sample of Brazilian individuals confirmed the results obtained through the statistical analysis performed. The study of essential determinants to the construction of the biological profile in forensic practice. such as sex. age. ancestry and stature. constitute fundamental pieces for the future of Forensic Anthropology. 
The increase of reliable methodologies available and their respective validations in the most diverse Populations around the world are essential for the optimization and qualification of anthropological expertise in human identification services.

\section{Conclusion}

The analysis of the craniometric variables showed that there is sexual dimorphism between skulls of the analyzed sample. The elaborated discriminant formulas and the reference table presented satisfactory results for sex estimation in a Brazilian population, the multivariate discriminant analysis of the cranial measurements of the Brazilian sample showed a percentage of accuracy between $82-90 \%$. The validation process of the discriminant functions and the reference table showed a percentage of accuracy between-74.2-85.7\%. The results found in the present study shows that the methodology proposed can be applied in the analysis of Brazilian forensic cases, helping the nationals human identification services.

\section{Acknowledgments}

This investigation was fund by the State of São Paulo's Research Fund (FAPESP, processes numbers 2012/19111-4 and 2014/13340-7)).

\section{References}

Cattaneo C (2007) Forensic anthropology: developments of a classical discipline in the new millennium. Forensic Science International 165: $185-193$.

Cunha, E., \& van Vark, G. N. (1991) The construction of sex discriminant functions from a large collection of skulls of known sex. International Journal of Anthropology 6: 53-66.

Dayal, M. R., Spocter, M. A., \& Bidmos, M. A. (2008) An assessment of sex using the skull of black South Africans by discriminant function analysis. HOMO - Journal of Comparative Human Biology 59: 209-221.

de Moura, R. R., Coelho, A. V. C., Balbino, V. Q., Crovella, S., \& Brandão, L. A. C. (2015) Meta-analysis of Brazilian genetic admixture and comparison with other Latin America countries. American Journal of Human Biology 27: 674-680.

de Oliveira, O. F., Tinoco, R. L. R., Daruge Júnior, E., Terada, A. S. S. D., da Silva, R. H. A. et al. (2012) Sexual dimorphism in Brazilian human skulls: discriminant function analysis. The Journal of Forensic Odonto-Stomatology 30: 26-33.

Dirkmaat, D. C., Cabo, L. L., Ousley, S. D., \& Symes S. A. (2008) New perspectives in forensic anthropology. American Journal of Physical Anthropology Suppl 47: 33-52.

Dong, H. M., Deng, M. H., Wang, W. P., Zhang, J., Mu, J. et al. (2015) Sexual dimorphism of the mandible in a contemporary Chinese Han population. Forensic Science International 255: 9-15.

Edwards, K., Viner, M. D., Schweitzer, W., \& Thali, M. J. (2013) Sex determination from the foramen magnum. Journal of Forensic Radiology and Imaging 1: $186-192$.

Ekizoglu, O., Hocaoglu, E., Inci, E., Can, I. O., Solmaz, D. et al. (2016) Assessment of sex in a modern Turkish population using cranial anthropometric parameters. Legal Medicine 21: 45-52.

Fatah, E. E. A., Shirley, N. R., Jantz, R. L., \& Mahfouz, M. R. (2014) Improving Sex Estimation from Crania Using a Novel Three-dimensional Quantitative Method. Journal of Forensic Sciences 59: 590-600.

Franklin, D., Cardini, A., Flavel A., \& Kuliukas A. (2013) Estimation of sex from cranial measurements in a Western Australian population. Forensic Science International 229: 158 e151-158.

Franklin, D., Freedman, L., \& Milne, N. (2005) Sexual dimorphism and discriminant function sexing in indigenous South African crania. HOMO - Journal of Comparative Human Biology 55: 213-228.

Galdames, I. C. S., Russo, P. R., Matamala, D. A. Z., \& Smith, R. L. (2009) Sexual Dimorphism in the Foramen Magnum Dimensions. International Journal of Morphology 27: 21-23.

Gapert, R., Black, S., \& Last. J. (2009) Sex determination from the foramen magnum: discriminant function analysis in an eighteenth and nineteenth century British sample. International Journal of Legal Medicine 123: 25-33.

Ilguy, D., Ilguy, M., Ersan, N., Dolekoglu, S., \& Fisekcioglu, E. (2014) Measurements of the Foramen Magnum and Mandible in Relation to Sex Using CBCT. Journal of Forensic Sciences 59: 601-605.

Inoue, M., Inoue, T., Fushimi, Y., \& Okada, K. (1992) Sex determination by discriminant function analysis of lateral cranial form. Forensic Science International 57: 109-117. 
Research, Society and Development, v. 10, n. 10, e266101018760, 2021

(CC BY 4.0) | ISSN 2525-3409 | DOI: http://dx.doi.org/10.33448/rsd-v10i10.18760

Kamath, V. G., Asif, M., Shetty, R., \& Avadhani R. (2015) Binary Logistic Regression Analysis of Foramen Magnum Dimensions for Sex Determination. Anatomy Research International: 9.

Kanchan, T., Gupta, A., \& Krishan, K. (2013) Estimation of sex from mastoid triangle - A craniometric analysis. Journal of Forensic and Legal Medicine 20: $855-860$.

Kent, M., Santos, R. V., \& Wade P. (2014) Negotiating Imagined Genetic Communities: Unity and Diversity in Brazilian Science and Society. American Anthropologist 116: 736-748.

Konigsberg, L. W., Algee-Hewitt, B. F. B., \& Steadman, D. W. (2009) Estimation and evidence in forensic anthropology: Sex and race. American Journal of Physical Anthropology 139: 77-90.

Kranioti, E. F., Iscan, M. Y., \& Michalodimitrakis, M. (2008) Craniometric analysis of the modern Cretan population. Forensic Science International 180: 110 e111-115.

Matamala, D. A. Z., Galdames, I. C. S., \& Smith, R. L. (2009) Sexual Dimorphism Determination from the Lineal Dimensions of Skull. International Journal of Morphology 27: 133-137.

Ousley, S., Jantz, R., \& Freid, D. (2009) Understanding race and human variation: Why forensic anthropologists are good at identifying race. American Journal of Physical Anthropology 139: 68-76.

Pena, S. D. J., Di Pietro, G., Fuchshuber-Moraes, M., Genro, J. P., Hutz, M. H. et al. (2011) The Genomic Ancestry of Individuals from Different Geographical Regions of Brazil Is More Uniform Than Expected. PLoS ONE 6: e17063.

Raghavendra Babu, Y. P., Kanchan, T., Attiku, Y., Dixit, P. N., \& Kotian, M. S. (2012) Sex estimation from foramen magnum dimensions in an Indian population. Journal of Forensic and Legal Medicine 19: 162-167.

Saini, V., Srivastava, R., Rai, R. K., Shamal, S. N., Singh, T. B. et al. (2011) An Osteometric Study of Northern Indian Populations for Sexual Dimorphism in Craniofacial Region. Journal of Forensic Sciences 56: 700-705.

Saini, V., Srivastava, R., Rai, R. K., Shamal, S. N., Singh, T. B. et al. (2012) Sex Estimation from the Mastoid Process Among North Indians*. Journal of Forensic Sciences 57: 434-439.

Traithepchanapai, P., Mahakkanukrauh, P., \& Kranioti, E. F. (2016) History. research and practice of forensic anthropology in Thailand. Forensic Science International 261: 167 e161-166.

Uthman, A. T., Al-Rawi, N. H., \& Al-Timimi, J. F. (2012) Evaluation of foramen magnum in gender determination using helical CT scanning. Dentomaxillofacial Radiology 41: 197-202. 